\title{
Sustainable historic waterfront development: approaches and dilemma of two UNESCO world heritage sites in Malaysia
}

\author{
S. Shamsuddin ${ }^{1}$, A. B. Sulaiman ${ }^{1}$, N. S. A. Latip ${ }^{2}$, R. C. Amat ${ }^{1}$ \\ \& N. A. Alias ${ }^{1}$ \\ ${ }^{1}$ Universiti Teknologi Malaysia, Malaysia \\ ${ }^{2}$ International Islamic University of Malaysia, Malaysia
}

\begin{abstract}
Urban waterfronts are unique cultural resources which have great potential to improve economic development, public enjoyment and civic identity. This issue is more predominant in the historic areas where the once active waterfront ceases to function in its traditional capacity. George Town and Melaka were both jointly awarded the UNESCO world heritage site in 2008 because of the similarity in issues and the functions they served in the past. The waterfronts of the cities were included in the heritage sites' boundaries and the approaches taken to the waterfront development have an important influence on their sustainability. This paper examines the approach to waterfront regeneration in the major cities of Malaysia including the two aforementioned historic cities. A mixed method approach has been adopted for the research using field observations, morphological study, in depth interview, questionnaire survey and content analysis of policies in government documents to collect data for the analysis. The research attempts to compare the differences in approaches between the two heritage cities and their implications in relation to their sustainability. The research discovers that the level of contextual integration is an important consideration for sustainable waterfront regeneration for the historic cities.
\end{abstract}

Keywords: waterfront, sustainable development, urban design and public place.

\section{Introduction}

Urban waterfronts are the types of cultural resources that have unique potential to improve economic development, public enjoyment and civic identity. 
Malaysia's Department of Drainage and Irrigation [7] defines the waterfront as an area within 50 metres or two lots of building from the banks where water is visually noticeable. In the past, the waterfront has been used extensively for land filling operation where the practice presents two major problems; one being unconsolidated fill and toxic material. The other problem as observed in Malaysia and Jamaica is the disregard of the heritage value (Fagence and CraigSmith [8]). As a result of the declining shipping industry, many towns are facing uncertain futures and the waterfront becomes a derelict part of the town. In making the waterfronts respond sensitively to its context, there must be a balance between economic gain as well as cultural gain. The historic waterfront is now relevant in the future because it provides opportunities for cities to be reconnected with their water bodies. There is also demand for culturally- and leisurely-oriented waterfront where heritage buildings are re-used for tourismrelated activities.

Krieger [18] contemplates that the success and appeal of the waterfront is intrinsically tied to the interrelationship between land side and waterside edges together with the quality of both water and shore. Some cities are taking efforts to preserve and suggest adaptive reuse of the heritage buildings and old waterfront structures which profits the communities' economy instead of allowing them to decay through neglect (Breen and Rigby [1]). In Malaysia, the historic waterfronts have now become the focus of new development ever since the successful completion of the waterfront development of Kuching - the capital city of one of the states in Malaysia - in 1993. Many opportunities for successful redevelopment have emerged in the rehabilitation of urban waterfront areas in which recreation and tourism become a catalyst for redevelopment (Fagence and Craig-Smith [8]) This paper will examine the approaches and the dilemma faced in regenerating the historic waterfronts of Melaka and George Town, the two Malaysian historic cities which received a joint status as World Heritage sites in July 2008. The issues of sustainable development in this context are examined from the social sustainability perspective where one of the aspects of social sustainability relates to quality of life. Quality of life is achieved through the ability of the city to provide for the basic needs of the residents of which having sense of place and identity is one of its requirements. Fenke Adriaens et al. [16] stress that vision of sustainability is strongly influenced by the dominant culture in which it is found not just in the object itself but also in the idea behind it. The meanings can be more sustainable than the object itself. Thus this paper discusses the sustainability of the historic waterfront in terms of its ability to retain its sense of place and perceived by the people as giving the identity to the city. This is due to the close relationship between place identity and cultural sustainability where in the age of globalisation, retaining local place identity is an important sustainable development agenda for any country.

\section{Literature review}

Jinnai [15] and Marshall [21] highlight that waterfronts have a potential role as new public places and nodes for the urban centres. McNulty and Hunter [22] 
opine that the public has had a change of attitude and perception towards the waterfront in the last decade and that the waterfront is now seen as an important public realm. In creating a sustainable waterfront development, urban design principles and factors are used as a tool to create a better public realm (Hoyle [14]) There is growing interest in urban design from many quarters due to various concerns 'in making places and improving the quality of the urban environment' in the public realm (Carmona et al. [3]; Carmona and Tiesdell [4]). With the acceptance of the contextual importance in the urban development in the aftermath of modernism (Greed and Roberts [10]) there is a change of attitude towards the once neglected urban rivers. The water bodies are now acknowledged as important elements of the city context because they give character to the city (Shamsuddin and Sulaiman [25]; Tweed and Sutherland [28]).

Waterfront redevelopment has started with the efforts of urban regeneration as a result of deindustrialisation (West [29]) The main aim of waterfront redevelopment is to provide new urban spaces with the opportunities to reintegrate the city with its waterfront (Falk [9]). Falk mentions that Jim Rouse's concept of 'festival market place' for Boston and Baltimore became a 'prepackaged' template for other waterfront projects all over the world. The copying of ideas in inappropriate circumstances can lead to development scheme lacking in character and failed to attract the necessary range of activities. Hagerman [11] further argues that many developments damaged the integration of the natural system into the urban area instead of enhancing it. This is despite of access to nature being acknowledged as having an important contribution to the community's well-being. The insertion of 'nature' in the urban planning of the waterfront is not aligned with the needs of the locality where redevelopment fails to prevent the impact of the city to the key areas of the physical environment such as the water (Cowell and Thomas [6]). Kawasaki et al. [17] and Yamashita and Hirano [30] also argued that most of the waterfront redevelopments do not take into consideration the relationship with the water.

According to Petrillo et al. (in [22]) previous waterfront designers' concentrated on the structure and the components part but gave insufficient thoughts to the scenic view, public access to the water edge and the ecologically sensitive areas. This however changed when recently, many cities have introduced guidelines or design parameters to control the situation from becoming worse. The change in public attitude and perception towards the waterfront as observed by McNulty and Hunter [22] saw many cities finding their form through the vision of a city on the waterfront.

According to Boyko et al. [2] a sustainable approach to redevelop waterfronts is growing where sustainability through urban design is acknowledged to be important in the redevelopment process (Porta and Renne [24]). In fact, sustainability exposes the essence of urban design which is to achieve durability in the midst of change. Fagence and Craig-Smith ([8]) argue that, waterfronts can be developed to be a catalyst to redevelopment projects based on tourism and recreation activities. However, in sustaining the project, the locals' needs and the context have to be taken into consideration. A 'balanced incremental approach' 
of development where each project is a comprehensive scheme that 'meets comprehensive needs of the community ensure that the redundant waterfront that was brought back to life becomes an asset that is appreciated by all. The locals' sense of belonging towards the development is imperative in ensuring that the redevelopment is sustainable. Generally, there is growing concern regarding the importance of connecting back to the water to achieve a better quality urban environment. This is a predominant phenomenon in Malaysian waterfront cities.

\section{Research methods and study area}

A mixed method approach was employed in the research. The approaches to the waterfront development and its effects to the character of the place are assessed by examining the changes to the waterfront area and the current physical characteristics through visual observation. The historical evolution of the urban fabric is traced by examining the old maps and photographs as well as historical documents and old newspaper articles that describe the character of the two cities. This is supported by interviews with representatives of the local authorities of the two cities to ascertain the approaches taken. A content analysis of the local plans and other documents produced by the authorities is also conducted.

A visual survey as suggested by Breen and Rigby [1] was conducted to record the present condition using photographic recording and mapping where the types, locations of development, quality of views and access along the waterfront areas were recorded. Finally, a questionnaire survey of 150 respondents comprising of users of the waterfront in both cities was employed to ascertain the user perception of the waterfront that influences the use of the waterfront and its contribution to their livelihood.

The two study areas differ in terms of its setting where Melaka is located by the river mouth opening to the Straits of Melaka south of the nation's Capital City, Kuala Lumpur whereas George Town is located on the Penang Island north of Kuala Lumpur. George Town has a larger core area (three times larger than Melaka) of 109.38 ha and a buffer zone of 150.04 ha as compared to Melaka in which the core zone is 38.62 ha. and a buffer zone area of 134.03 ha (Figure 1). Although both used to be port cities during the spice trade, Melaka has ceased its port activities due to shallow waters as a result of sedimentation. It also has embarked on a land reclamation program since the 1920 s to deal with this problem; thus affecting the original setting of its historic centre that now lies in the World Heritage Site boundaries. George Town, on the other hand, remains as in its original setting.

\section{Approaches to waterfront development and its effects on the physical evolution of the historic waterfront}

Both Melaka and George Town were both colonial cities where the founding of George Town represents the peak of British colonisation era from the end of $18^{\text {th }}$ century. However, Melaka's history originates in the $15^{\text {th }}$ century through 


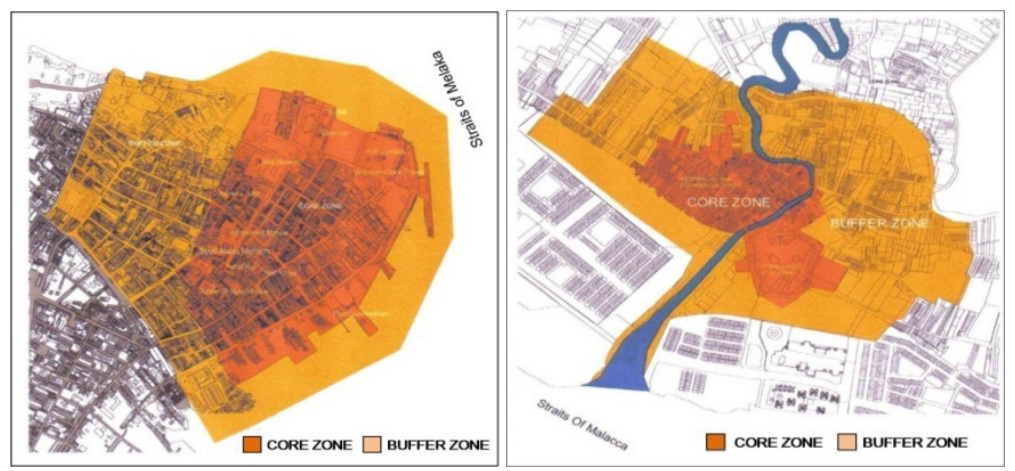

Figure 1: $\quad$ Boundaries of the world heritage site of historic city of Melaka (left) and historic city of George Town (right) (source: Nomination dossier for historic cities of straits of Melaka (2008)).

the Malay sultanate period with the colonial influence through the arrival of the Portuguese and Dutch only began in the early $16^{\text {th }}$ century. The Melaka River played an important role during the 1400s with many earlier residential areas built along the riverfront with a fortress and trading activities concentrating on the western banks close to estuary. Its urban form showed close similarities with other Dutch port-towns such as the presence of its main administrative building known as the Stadthuys, a main street and a canal built across the town with a special area for civilian residents. The A'Famosa fort in Melaka was bombed by the British in order to attract port trading activities to focus in George Town. The city embarked on an extensive reclamation of its seashore area in 1971 which affects Melaka's historic centre profile and original setting from fronting the sea to fronting the river. The reclamation which began as early as 1921 during the colonial era due to sedimentation problems had changed. There is no visual access to the sea from the designated UNESCO world heritage site.

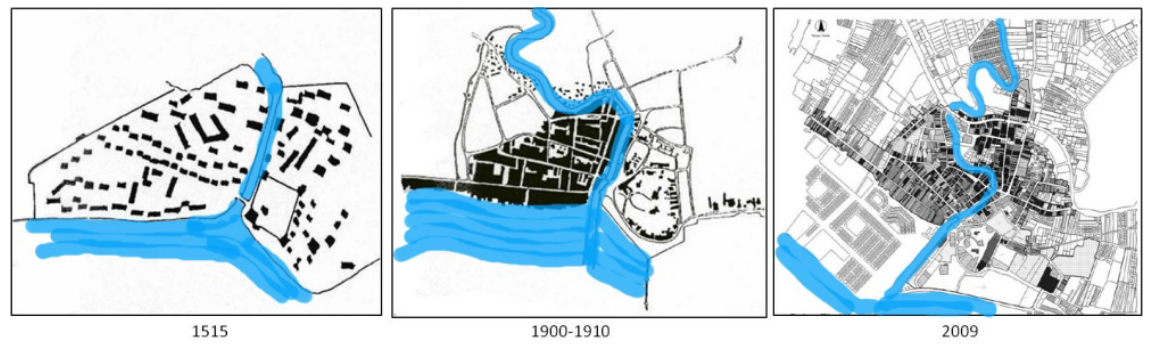

Figure 2: The morphology of Melaka (source: Shuhana and Bashri (1992)).

The Melaka's city local authority with the help of the Melaka Museum Corporation has prepared an action plan for the conservation area which consists of specific guidelines based on UNESCO's guidelines on heritage sites. The guidelines are available as a reference to keep future developments in line with 
its conferred status. There is a specific guideline given to the Melaka River where the guidelines mainly focus on increasing public access to the riverfront. The Melaka River used to have many residential buildings with illegal extensions along the water edges to accommodate the toilets. The river used to be polluted where the physical and visual access to the river front is rather limited. However, since 2005, the Melaka administration has taken a pro-active measure to revive the river through a costly regeneration project that transforms the riverfront. The project has cleared the illegal extensions on the river and improves the water quality through a river cleaning program.

A pedestrian walkway, river boat cruise and a small theme park have been built to serve the growing demand for leisure and recreational activities. The squatters along the upper parts of the river have also been relocated and replaced with board walks where the mangrove swamps are still being preserved along the river. Accordingly, the regeneration of the riverfront has given the city an additional public space to provide for the recreational needs that can strengthen the sense of belonging to the riverfront. With the increase in the visual and physical access to the river, the regeneration project has successfully improved the contextual integration between the city and the water.

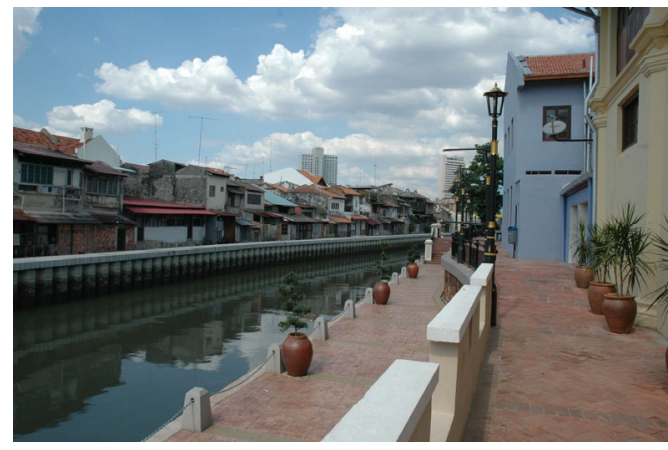

Figure 3: Improved riverfront access in Melaka.

Between 1786 until 1790, George Town's development was focused along the waterfront when where a fortress complex called Fort Cornwallis was built to accommodate the garrison and many important buildings of the British administration. The developments of shophouses, buildings, residential areas as well as Fort Cornwallis and the Acheh village's mosque created an attractive scenery and urban form of George Town. The main streets such as Jalan Masjid Kapitan Keling acted as a backbone to support the main developments especially along the waterfront. Historically, the stretch of seafront of George Town was reclaimed and named "Weld Quay" after Sir Frederick Weld, the Governor of the Straits Settlements. The Penang harbour had a few piers such as Victoria Pier (1888), Church Street Pier/Railway Jetty (1897), Swettenham Pier (1904) and TunUda Pier (Ferry Terminal) (1959). The Weld Quay stretched from Swettenham Pier to Pragin River and connected by ghauts (the stone/wooden or wooden jetty as an extension of the street from the shore to inland). 
In 1901, most of the developments were created in the brownfield area and on the open spaces between the buildings. The transportation system was also improved during this time. The clan jetty along the waterfront was the only residential area on the waters housing the Chinese workers who came from mainland China. This was in the form of houses built on stilts attached to a jetty on the waters, where people who came from the same clans would build their houses attached to their clan jetty (Figure 4). The historical George Town waterfront features such as the clan jetties (Weld Quay) have physically survived the threats of urbanization and development but their socio-cultural composition has been transformed and is facing the threat of extinction. These clan jetties have become a low income urban community settlement rather than the historic waterfront legacy lineage (clan) identity and communal site of floating dwellings (water villages). Today, there is no major development along the waterfront apart from the marina and the commercial buildings near the ferry port area. George Town has also lost its traditional sea facing orientation with the most of its waterfront being off-limits to the public.

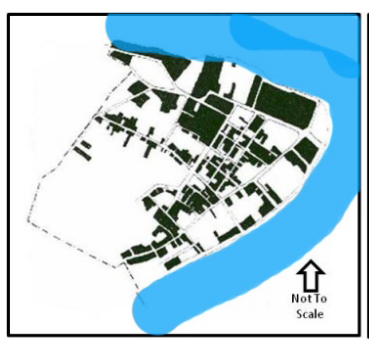

$1891-1900$

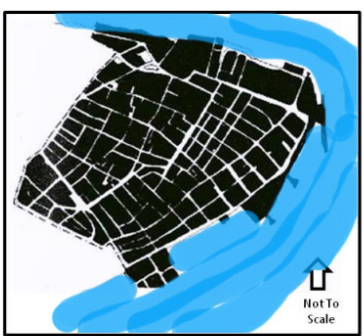

$1991-1998$

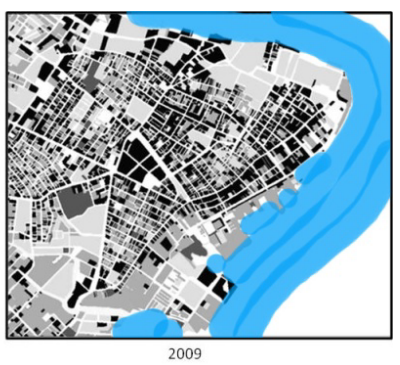

Figure 4: The morphology of George Town (source: Shuhana et al. (2002)).

However, unlike Melaka, the George Town waterfront has not changed significantly in terms of use with many of the previous activities such as port ferry terminals, Fort Cornwallis and the clan jetty still remain in their original location.

The other parts of the waterfront i.e., the port and custom buildings area, the marina development and the clan jetty are still visually blocked with limited public access. The pedestrian linkages along the waterfront are also not continuous. The bus station that is located near the ferry terminal contributes to the noise and air pollution together with the increase of congestion along the waterfront.

The Special Area Plan for George Town 2011 has identified several strategies and performance criteria which will, hopefully, improve the contextual integration between the waterfront and the city.

The strategy for waterfront connectivity includes linkages from the waterfront area (Weld Quay especially) into the inner city which are proposed to facilitate pedestrian movement within the areas. A water taxi route is proposed to connect key areas along waterfront. Several waterfront promenades were also proposed 


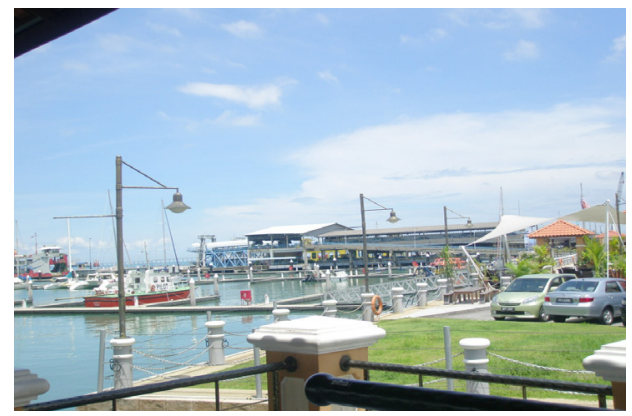

Figure 5: $\quad$ Marina at George Town.

along the Esplanade and Fort Cornwallis, Upper Weld Quay Waterfront Promenade and Clan Jetties Waterfront Promenade.

Performance Criteria for the Waterfront Promenades are also established which includes public accessibility, compliance to universal design principles, possible integration with the landscape and storm water management system, recovers, re-uses and generally minimizes the amount of natural resources used, possible incorporation of street makers along heritage trails to increase legibility and way-finding, minimal design for new street furniture and lighting and possible incorporation of historic street furniture, either restored or authentically reconstructed.

An organization called Think City has been set up by the central government to monitor the conservation works in the sites where funds are available to conduct restoration works. The organization works very closely with the local residents in improving the conditions of the heritage buildings. However, most of the works conducted are away from the historic waterfront. It can be seen that George Town's policies are addressing the issues of the waterfront in a more detailed manner compared to Melaka. However, the latter's approach to waterfront regeneration in world heritage sites has been translated in its riverfront promenade project whereas George Town has yet to realize the recent policies.

\section{The historic waterfront from users' perspectives}

The users' perception of the waterfront in both cities was obtained through a sample survey of 150 users from both cities selected using a time interval sampling technique. Despite the difference in approaches towards the historic waterfront, there is no significant difference between the users of both cites. A majority of the respondents in both cities are satisfied with the conditions of the waterfront where a high majority of them love to visit the waterfront in both cities although the visits are not that frequent. The waterfront is also an important place to a significant number of the respondents where these places make a strong impression on the users in their image of the two cities. 
After the revitalization of the Melaka River, its waterfront is more accessible to the respondents in comparison to George Town where the nature of development and traffic network has limited public access to the waterfront. The city centre's commercial area is also located quite far from the waterfront as compared to Melaka. The main attraction of the George Town waterfront as compared to Melaka is the physical characteristics and activities whilst Melaka's main attractions to the respondents are its physical characters. There is also a high degree of association between the waterfront and the city's identity as observed by the feedback of the respondents from both cities. This is evident when $53 \%$ of the respondents for George Town visit the waterfront for recreational purposes whereas the Melaka respondents come to visit the city rather than coming for specific purposes associated with the waterfront. George Town's waterfront also has a more functional role to the users indicating that the sense of place is influenced by its activities.

Melaka's physical changes to the waterfront such as its extensive land reclamation and riverfront development are also noticeable by the respondents as compared to George Town. The regeneration of the riverfront has made more people aware of the river whereas the reclamation of the sea front has set the historic centre as being away from the sea unlike its original sea front setting. Despite the drastic changes to its waterfront the Melaka respondents are satisfied with them compared to the respondents of George Town. However, the majority of respondents in both cities do not agree to any reclamation works to be done on the waterfront where Melaka's respondents register a higher percentage for those who identify that there are problems along the waterfront as compared to the George Town's respondents. The majority of the respondents for both cities find that the waterfront areas do not have any significant problem as compared to other areas. Both cities have a high degree of accessibility to the waterfront according to the respondents where George Town's waterfront is less visible than Melaka. The latter can be now easily spotted from the city centre due to the presence of promenade along the river that runs through it. The survey suggests that the waterfront is highly prominent to the users and that it serves as an important public realm that fulfils their recreation needs. The users' perception of the waterfront is also not affected by the development along it and therefore does not affect their perception of the place. Despite some physical changes to the waterfront, such changes do not affect their perception of the sense of place of both cities.

\section{Conclusion}

The joint status of world UNESCO heritage sites has put both cities in the limelight in terms of their efforts in safeguarding their character to warrant the prestigious listing. Advice from experts all over the world were sought to restore and conserve the built heritage. George Town has already received a yellow flag for allowing development not in keeping with the context to be developed in the heritage sites. It also puts the pressure on the relationship between the two cities as a result of the joint status where the loss of the status of one will affect the 
other. The dilemma is how to approach its waterfront development sensitively to meet the increasing demands for recreation and tourism and yet safeguard its authenticity in historic character. Although Melaka has lost its seafront setting as a result of the reclamation works, it has taken advantage of its riverfront for the integration of its riverfront with the city. George Town is less forceful in regenerating its historic waterfront after receiving the yellow flag from UNESCO. The release of the local plan for the sites which includes the waterfront area last year will lead to a more integrated approach towards the waterfront that promises for a public realm to be created thus giving back the waterfront to the public. It is observed that the issue of the waterfront especially having the status of a UNESCO World Heritage Site must be dealt by having a strong vision to bring the historic waterfront closer to the city where guidelines are needed to guide future development to secure their sense of place.

\section{Acknowledgements}

The authors would like to acknowledge the Ministry of Science, Technology and Innovations Malaysia (MOSTI), for sponsoring the research under its E Science Funds and the Research Management Centre, Universiti Teknologi Malaysia for facilitating the management of this research.

\section{References}

[1] Ann Breen and Dick Rigby, 1996. The New Waterfront: A Worldwide Urban Success Story, McGraw Hill

[2] Boyko, C. T., Cooper, R. and Davey, C., 2005. Sustainability and the Urban Design Process. Engineering Sustainability September. 158 Institution of Civil Engineers, pp. 119-125.

[3] Carmona, M., Heath, T., OC, T. and Tiesdell, S., 2003. Public places urban spaces. The dimensions of urban design. Oxford: Architectural Press.

[4] Carmona, M. and Tiesdell, S. eds., 2007. Urban design reader. Oxford, UK: Architectural press.

[5] London: Institute of British Geographers Publication 27.

[6] Cowell, R. and Thomas, H., 2002. Managing nature and narratives of dispossession: reclaiming territory in Cardiff Bay. Urban studies, 39(7), 1241-1260.

[7] Department of Drainage and Irrigation, Guideline on Facing the River Concept Department of .Drainage and Irrigation, Editor. 2003, Department of Drainage and Irrigation.

[8] Fagence, M. and Craig-Smith, J. S. eds., 1995. Recreation and tourism as a catalyst for urban waterfront redevelopment. Westport: Prager Publishers.

[9] Falk, N., 1992. Turning the tide: British experience in regenerating urban docklands. In: Hoyle B.S and D.A, P. eds. European port cities in transition. London: Belhaven Press, pp. 116-135.

[10] Greed, C. and Roberts, M. eds., 1998. Introducing urban design. Essex, England: Addison Wesley Longman Limited. 
[11] Hagerman, C., 2007. Shaping neighbourhoods and nature: Urban political ecologies of urban waterfront transformations in Portland, Oregon. Cities, $1-13$.

[12] Hoyle BS, Pinder DA and Husin MA, 1988 Revitalising the Waterfront: International Dimension of Docklands Redevelopment John Wiley \& Sons Inc.

[13] Hoyle, B., 1992. Cities and the sea. Change and development in contemporary Europe. In: Hoyle, B. and Pinder, D. eds. European Port cities. London: Belhaven Press.

[14] Hoyle, B., 2001. Waterfront revitalisation in an East African Port-city. Cities, 18(5), 297-313.

[15] Jinnai, H., 2001. The waterfront as a public place in Tokyo. In: MIAO, P. ed. Public places in Asia Pacific Cities. Netherlands: Kluwer Academic Publisher.

[16] Fenke Adriaens et al., 2005. Sustainable Urban Design. Netherlands: Blauwdruke Publishers Wageningen.

[17] Kawasaki, M., Sasaki, T. and Yang, H., 1995. An analysis of image in waterfront cities. In: CRAIG-SMITH, J. S. and FAGENCE, M. eds. Recreation and tourism as a catalyst for urban waterfront redevelopment. Westport: Praeger, pp. 118-125.

[18] Krieger A. 2004, Remaking of Urban Waterfront. ULI Press. 22.

[19] Lynch, Kevin, The Image of the City, MIT Press, Cambridge MA 1960.

[20] May, R., 2006. "Connectivity" in urban rivers: Conflict and convergence between ecology and design. Technology in society, 28, 477-488.

[21] Marshall, R., Remaking the image of the city. Bilbao and Shanghai, in Waterfronts in Post-Industrial Cities, R. Marshall, Editor. 2001b, Spon Press: London.

[22] McNulty, R. H. and Hunter, P. A., 1985. The value of amenities: Waterfront restoration can pay off. In: Petrillo, J. E. and Grenell, P. eds. The urban edge. Where the city meets the sea. USA: The California State Coastal Conservancy and William Kaufmann Inc., pp. 86-93.

[23] Paumier C, 2004 Creating a Vibrant City Centre: Urban Design and Regeneration Principles Urban Land Institute, Washington.

[24] Porta, S. and Renne, J. L., 2005. Linking urban design to sustainability: Formal indicators of social urban sustainability field research in Perth, Western Australia. Urban design international, 10, 51-64.

[25] Shamsuddin, S. and Sulaiman, A. B., 2004. Urban regeneration through urban design in improving the quality of the built environment of historic cities. E Design Conference, Pan Pacific Kuala Lumpur, December 2004.

[26] Shamsuddin, S. and Sulaiman, A. B., 1992, Unpublished Research Report UTM.

[27] Shamsuddin, S, Sulaiman, A. B, Ali, M. K, Hussein, Z. M, Chau, L. W, Ahmad, H, Ahamad, A. 2002, Developing a guideline for designing urban intervention in places of historical cultural significance in Malaysia, Research vote no: 72216, Architectural Department, Universiti Teknologi Malaysia. 
[28] Tweed, C. and Sutherland, M., 2007. Built cultural heritage and sustainable development. Landscape and urban planning, 1-8.

[29] West, N., 1989. Urban waterfront developments: A geographic problem in search of a model. Geoforum, 20(4), 459-468.

[30] Yamashita, S. and Hirano, M., 1995. Residents' evaluation and the recreational uses of urban rivers. In: Craig-Smith, J. S. and Fagence, M. eds. Recreation and tourism as a catalyst for urban waterfront redevelopment. Westport: Praeger, pp. 127-134. 